\title{
OPEN
}

Published online: 10 March 2020

\section{Author Correction: Propagation and Selectivity of Axonal Loss in Leber Hereditary Optic Neuropathy}

\section{Razek Georges Coussa, Pooya Merat \& Leonard A. Levin (1)}

Correction to: Scientific Reports https://doi.org/10.1038/s41598-019-43180-Z, published online 30 April 2019

Supplementary files "Video 1" and "Video 2" were omitted from the original version of this Article. This has been corrected in the HTML version of the Article; the PDF version was correct at time of publication.

\begin{abstract}
(c) (1) Open Access This article is licensed under a Creative Commons Attribution 4.0 International License, which permits use, sharing, adaptation, distribution and reproduction in any medium or format, as long as you give appropriate credit to the original author(s) and the source, provide a link to the Creative Commons license, and indicate if changes were made. The images or other third party material in this article are included in the article's Creative Commons license, unless indicated otherwise in a credit line to the material. If material is not included in the article's Creative Commons license and your intended use is not permitted by statutory regulation or exceeds the permitted use, you will need to obtain permission directly from the copyright holder. To view a copy of this license, visit http://creativecommons.org/licenses/by/4.0/.
\end{abstract}

(c) The Author(s) 2020 